\title{
The survival and dispersal of Taenia eggs in the environment: what are the implications for transmission? A systematic review
}

\author{
Famke Jansen ${ }^{1 *}\left(\mathbb{D}\right.$, Pierre Dorny ${ }^{1}$, Sarah Gabriël ${ }^{2}$, Veronique Dermauw ${ }^{1}$, Maria Vang Johansen ${ }^{3}$ \\ and Chiara Trevisan ${ }^{1}$
}

\begin{abstract}
Taenia spp. are responsible for a substantial health and economic burden in affected populations. Knowledge of the fate of the eggs of Taenia spp. in the environment and of other factors facilitating the transmission of eggs to intermediate hosts is important for the control/elimination of infections caused by Taenia spp. The aim of this systematic review was to summarize current knowledge of the factors influencing the survival and dispersal of Taenia spp. eggs in the environment. Publications retrieved from international databases were systematically reviewed. Of the 1465 papers initially identified, data were ultimately extracted from 93 papers. The results of this systematic review indicate that survival is favoured at moderate temperatures $\left(0-20^{\circ} \mathrm{C}\right)$. Humidity seems to affect the survival of Taenia spp. eggs more than temperature. Under field circumstances, Taenia spp. eggs have been found to survive for up to 1 year. Taenia spp. eggs are commonly found on vegetables (0.9-30\%) and in soil and water samples (0-43\%), with their presence posing a risk to the consumer. Invertebrates may act as transport hosts, transferring the infection to an intermediate host, but the importance of this route of transmission is still open to question. Wastewater treatment systems are not capable of entirely eliminating Taenia spp. eggs. Access to surface water and the use of sewage sludge as fertilizer on pastures are important risk factors for bovine cysticercosis. Although information on the survival and spread of Taenia spp. eggs is available, in general the data retrieved and reviewed in this article were old, focused on very specific geographical regions and may not be relevant for other areas or not specific for different Taenia spp. Furthermore, it is unknown whether egg survival differs according to Taenia sp. Future studies are necessary to identify sustainable methods to identify and inactivate parasite eggs in the environment and reduce their spread.
\end{abstract}

Keywords: Taenia, Egg survival, Spread, Environment, Sewage treatment

\section{Background}

Taenia spp. are important tapeworm species in humans and domesticated animals that may lead to a substantial health and economic burden [1-3]. Humans are the sole definitive hosts of three zoonotic Taenia spp., namely $T$. saginata, $T$. solium and $T$. asiatica [4]. Other Taenia spp., such as T. hydatigena, T. pisiformis, T. ovis,

*Correspondence: fjansen@itg.be

1 Department of Biomedical Sciences, Institute of Tropical Medicine, 155 Nationalestraat, 2000 Antwerp, Belgium

Full list of author information is available at the end of the article
T. taeniaeformis and T. multiceps, are mainly of veterinary importance. Taenia saginata is the most common and most widely distributed tapeworm in the human host [5]. Taenia solium, on the other hand, is endemic in large parts of Asia, Latin America and sub-Saharan Africa, while T. asiatica seems to be restricted to Asia [3]. Infections with T. solium and T. asiatica are considered to be neglected tropical diseases, and especially for infections caused by the former, the call for control and elimination is warranted as the parasite can also cause cysticercosis in humans. The establishment of cysticerci in the central nervous system may lead to 
neurocysticercosis, which has been found to be associated with more than $30 \%$ of acquired epilepsy cases in endemic regions [6-9].

Humans become infected with $T$. saginata, T. solium and $T$. asiatica by consuming raw or undercooked infected beef, pork or pig organs containing cysticerci, the metacestode larvae of the tapeworm. Upon ingestion of a viable cysticercus, an adult tapeworm may develop that resides in the intestinal lumen of the human final host $[3,6]$. Infection with a tapeworm (taeniosis) generally remains asymptomatic $[10,11]$ with some exceptions [12-14].

Gravid proglottids containing infective eggs are shed with the stool of the definitive host; in the case of T. saginata they may also be expelled independently of defecation [3]. In industrialized countries, inadequately treated sewage is generally considered to contribute to infections in cattle by $T$. saginata, as animals become infected by ingesting the eggs from contaminated pastures after flooding or from access to surface water [11]. On the other hand, in low-income countries, humans contaminate the environment (soil, crops and water) with Taenia spp. eggs present in faeces due to poor hygienic standards and the lack of latrines [15]. In general, contamination of food, soil and water can increase the risk of infection for humans (T. solium) and other intermediate hosts (all Taenia spp.) [16-18], as does possible spread via invertebrates and wind $[19,20]$.

Control and treatment options for Taenia spp. have generally been generated from a two-compartment approach, with the focus either on the definitive host or on the intermediate host. Interventions for $T$. solium, including education, meat inspection, sanitation, treatment of final and intermediate hosts and pig vaccination, have been implemented, either as single interventions or in combination [21]. However, focus on the third compartment, namely the egg stage in the environment, has often been neglected even though tapeworms have the ability to produce up to 300,000 eggs each day [22]. Therefore, egg survival and dispersal studies can lead to new insights on the survival capacity of eggs and to possible new control options to break the life-cycle of these parasites and prevent infection of cattle, pigs and humans. In general, egg survival experiments are conducted under in vivo or in vitro conditions. In in vitro experiments, eggs are checked for viability based on integrity (mostly morphological determination), hatching and activation (movement of the larva after hatching), the latter two approaches performed in designated media mimicking gastric juices [23-25]. These terms are often used interchangeably, so caution is necessary when interpreting study findings.
In in vivo studies, egg infectivity is determined by feeding eggs to naïve intermediate host animals followed by dissecting the carcasses for cysticerci recovery [26].

The aim of the systematic review was to review current knowledge of the factors that influence the survival and dispersal of Taenia spp. eggs in the environment. More specifically, we aimed to summarize current knowledge on (i) the survival of Taenia spp. eggs under specific temperature and relative humidity (RH) conditions in laboratory and field experiments; (ii) the presence of eggs on vegetables, fruit, soil and water depending on the geographical area or climate zone of the study; (iii) the spread of eggs via different means, such as invertebrates and wind; and finally, (iv) the importance of sewage treatment systems in egg dispersal.

\section{Methods}

A systematic review of literature published up to 31 July 2019 was conducted to collect information on the survival and dispersal of Taenia spp. eggs in the environment, using an approach that followed PRISMA guidelines [27]. No restriction was made on publication date. The protocol and the PRISMA checklist for this review can be found in Additional file 1 and Additional file 2, respectively. Two search engines, PubMed (http://www.ncbi.nlm.nih.gov/pubmed) and Web of Science (www.webofknowledge.com), were searched without the use of a specific time frame and using the following keywords and Boolean opeators: taeni" AND egg* AND (surviv* OR viab* OR resist* OR longevi" OR

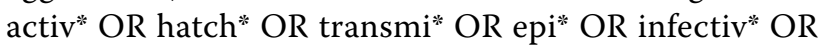
water OR wastewater OR sewage OR sludge OR river OR stream OR soil OR silt OR grass OR saline OR environment" OR medi*).

Outputs from the two search engines were first screened for the English language, and publications in languages other than English were excluded. The results were then compiled and screened for duplicates, after which titles and abstracts were screened for eligibility by two independent reviewers. Publications were excluded based on the following reasons: (i) studies on species other than Taenia spp.; (ii) studies outside the scope of this review (egg survival and dispersal), such as laboratory techniques for hatching; and (iii) reviews and editorial letters. Where possible, full texts were retrieved and evaluated according to the same criteria. The reference lists of each eligible article were also screened for relevant literature. Data were extracted from the records into predefined tables using Microsoft Excel (Microsoft Corp., Redmond, WA, USA). 


\section{Results}

A total of 1460 publications were identified through the database searches, and an additional five articles were identified after screening the relevant literature. Ninetythree studies were included in the systematic review after careful elimination of the remaining papers based on the exclusion criteria (Fig. 1).

\section{Egg survival}

Twenty-four studies were identified that investigated Taenia spp. egg survival in the environment. The studies shown in Table 1 describe laboratory or field experiments aimed at determining the survival of eggs after exposure to a range of temperatures and relative humidities, to different light types and to various media. In general, humidity seems to affect Taenia spp. egg survival more than temperature, with low humidity $(<34 \%)$ hampering survival. Moderate temperatures (between $5{ }^{\circ} \mathrm{C}$ and $25^{\circ} \mathrm{C}$ ) favour survival, while warmer temperatures $(>25$ ${ }^{\circ} \mathrm{C}$ ) and freezing shorten survival times. Under field conditions, survival is dependent on the specific Taenia sp. studied and the specific outdoor conditions. In one study on Kenyan pastures, eggs were observed to survive up to 1 year [28].
Studies investigating the effect of heat treatment (> $40^{\circ} \mathrm{C}$ ) were generally not directed at environmental factors affecting survival but more focussed on which factors were effective in destroying eggs (in this case, cooking or boiling of food and fluids). The ovicidal activity of several naturally occurring agents was investigated. A number of studies reported that the fungi Paecolimyces lilacinus and Pochonia chlamydosporia were able to colonize the egg contents of $T$. saginata and T. taeniaeformis eggs, which led to their destruction [29-33]. It was also reported that lime nitrogen had the most destructive effect on egg survival of all fertilizers tested, with the eggs only surviving for 2 days in this substance; survival in other fertilizers was 2 days in limestone, 10 days in ammonium nitrate with limestone, 3 days in superphosphate substance, 3-7 days in NPK3, 10 days in potash salt and 30-35 days in urea [34].

\section{Environmental spread of eggs}

A total of 43 papers, representing the majority of all publications retained in this review, described possible means of spreading of Taenia spp. eggs in the environment. Fifteen papers investigated the presence of helminth eggs on vegetables bought at markets, and a
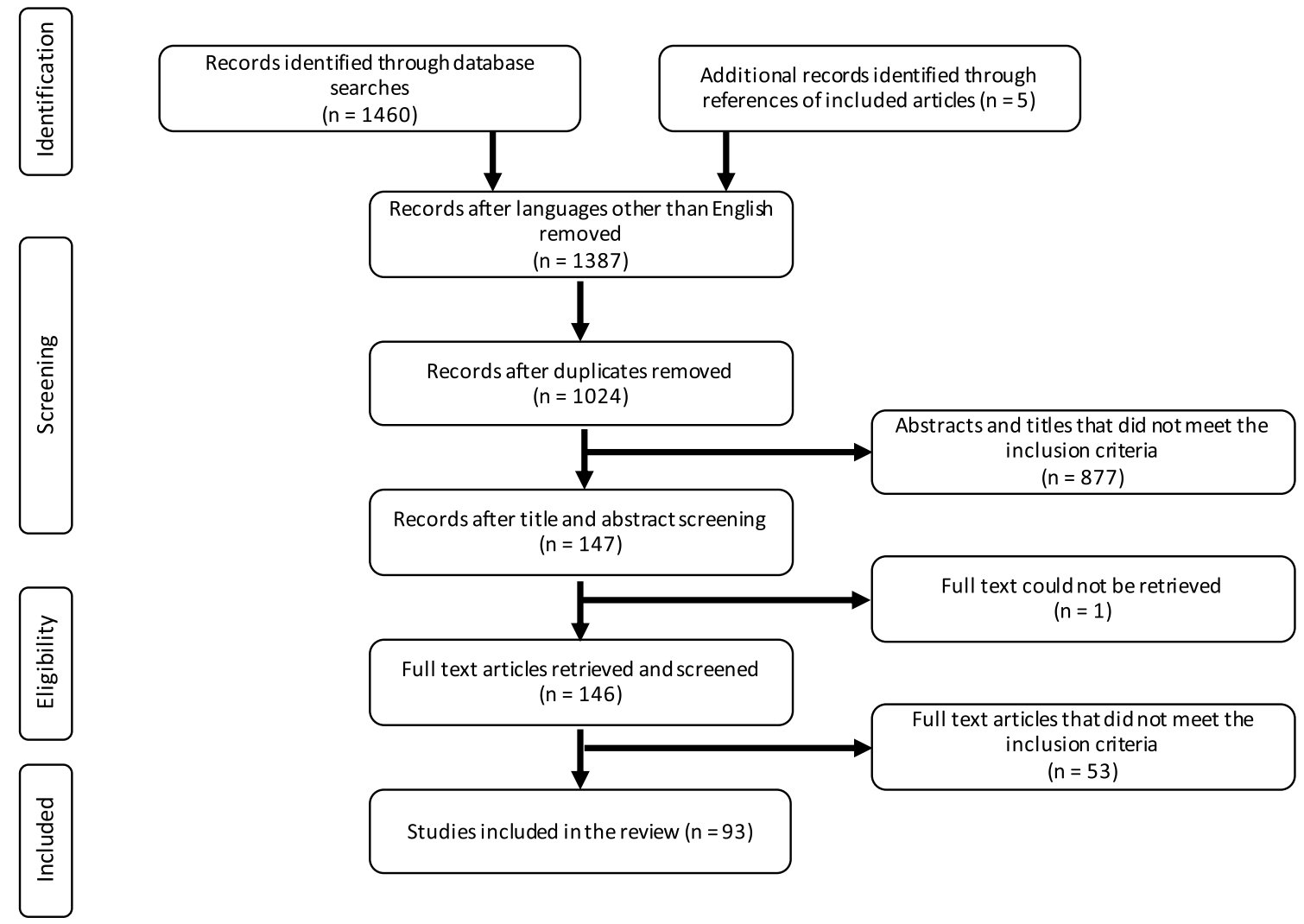

Fig. 1 Flow diagram of the database search 


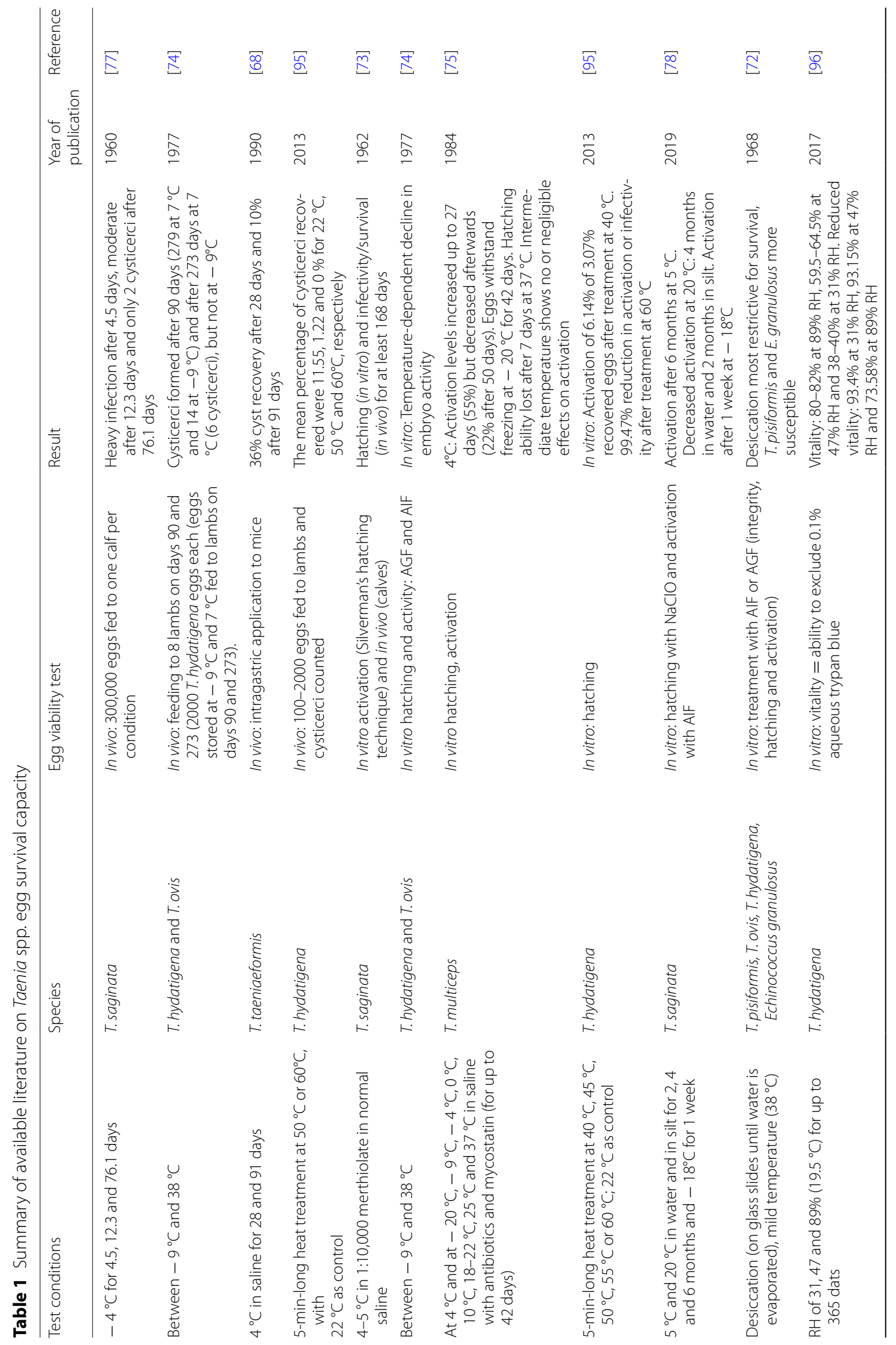




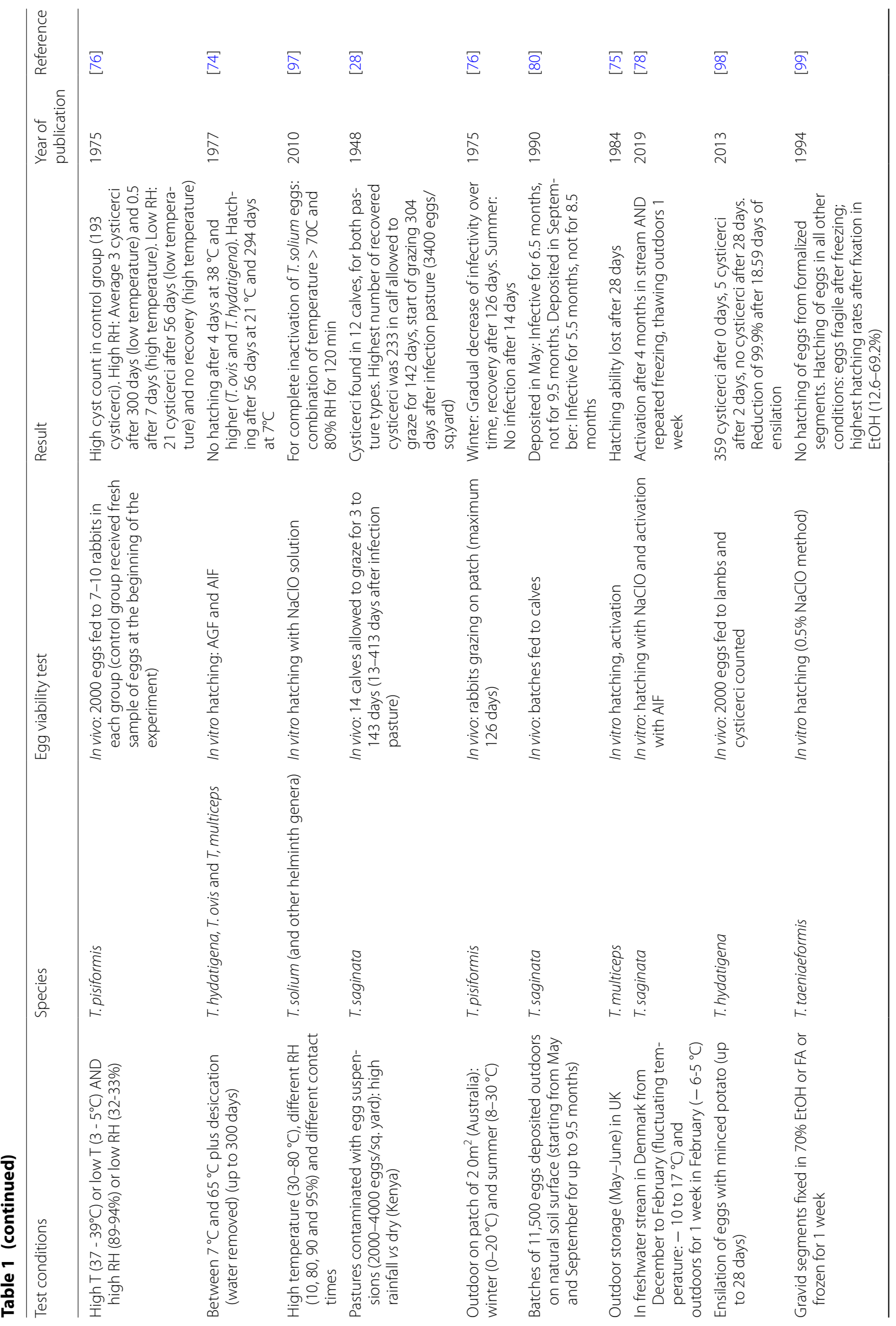




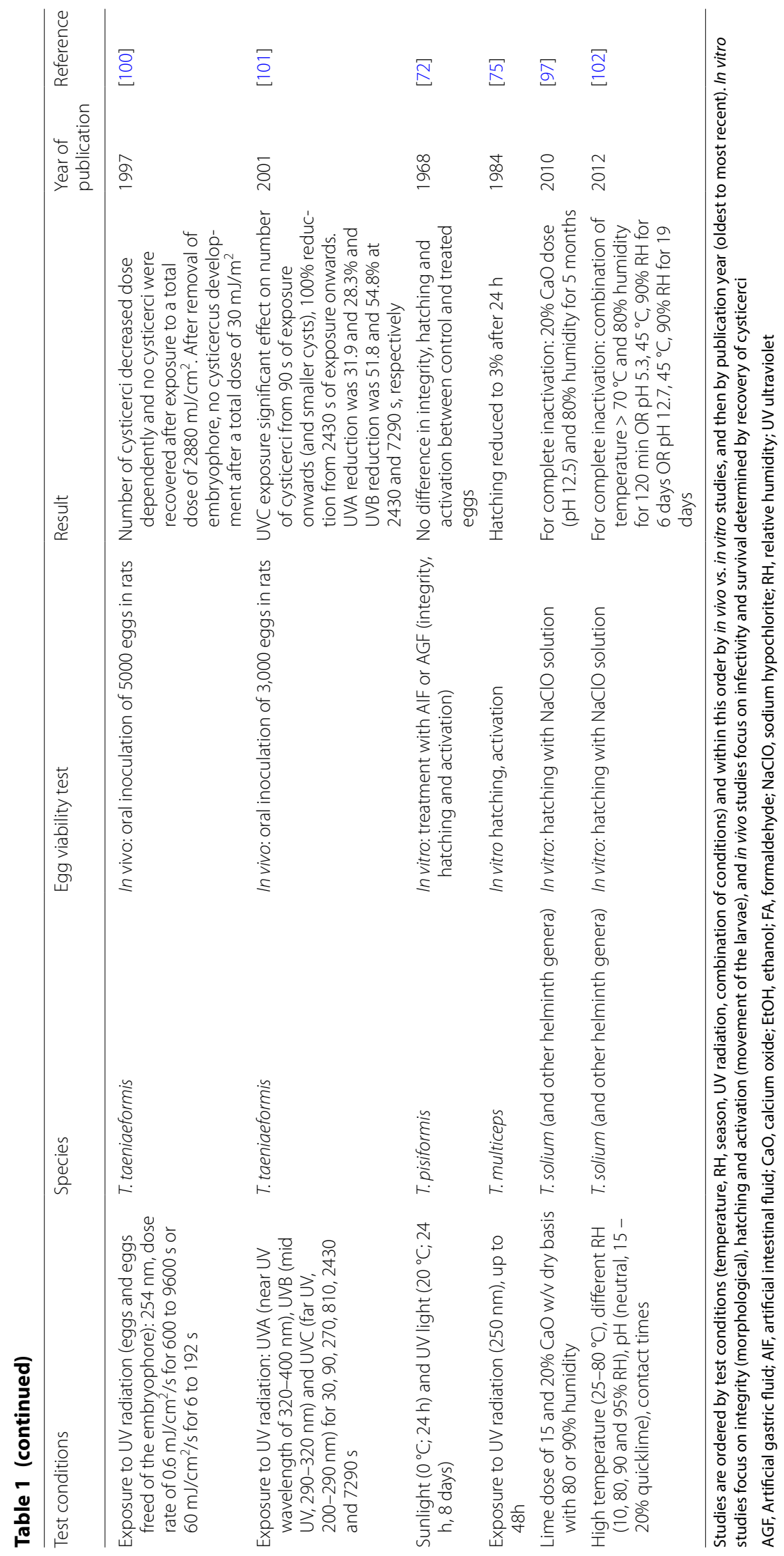


number also examined the effect of washing of vegetables on the number of eggs (Table 2). In general, prevalence of Taenia spp. eggs found on fruits and vegetables is high, ranging from 0.9 to $33 \%$.

Research on the contamination of fruits and vegetables has been conducted in only few countries and consequently in only a few climate zones. Although all five major climate zones are represented in the studies reviewed, many of the climate subdivisions are not. Survival of eggs was found to be very dependent on temperature and RH and, therefore, also on climate zone. The authors of most studies agreed that leafy vegetables had a higher prevelance of parasites than smooth vegetables, such as tomatoes and cucumbers [35-43]. Parasite egg prevalence in general, and the prevalence of Taenia spp. eggs specifically, was higher in the summer and spring compared to the winter and autumn $[37,44,45]$.

Federer et al. [17] studied the presence of taeniid DNA by multiplex-PCR in the water used to wash the fruit and vegetable mixes fed to zoo animals in Switzerland. The vegetables and fruits in the mix originated from all over Europe. In the autumn, $18 \%$ of the water samples contained taeniid DNA, compared to $28 \%$ in the spring.

Table 2 Overview of results on Taenia spp. egg prevalence on vegetables and fruit

\begin{tabular}{|c|c|c|c|c|c|}
\hline Country & Climate zone $\mathrm{e}^{\mathrm{a}}$ & $\begin{array}{l}\text { Taenia spp. egg prevalence before } \\
\text { washing, no species specified ( } N= \\
\text { sample size) }\end{array}$ & $\begin{array}{l}\text { Taenia spp. egg prevalence after } \\
\text { washing ( } N=\text { sample size) }\end{array}$ & $\begin{array}{l}\text { Year of } \\
\text { publication }\end{array}$ & Reference \\
\hline Iran & $\begin{array}{l}\text { Hot desert with Mediterranean and } \\
\text { continental hot summer climate } \\
\text { in the north }\end{array}$ & $0.9 \%(N=772)$ & $0(N=772)$ & 2016 & [41] \\
\hline Iran & $\begin{array}{l}\text { Hot desert with Mediterranean and } \\
\text { continental hot summer climate } \\
\text { in the north }\end{array}$ & $9.2 \%(N=304)$ & $\begin{array}{l}1.3 \%(N=304) \text { (traditional } \\
\left.\text { washing }{ }^{b}\right) \\
0\left(\text { standard washing }^{\mathrm{c}}\right)\end{array}$ & 2012 & {$[45]$} \\
\hline Iran & $\begin{array}{l}\text { Hot desert with Mediterranean and } \\
\text { continental hot summer climate } \\
\text { in the north }\end{array}$ & $\begin{array}{l}1.8 \%(N=218)(\text { Taenia/Echinococ- } \\
\text { Cus })\end{array}$ & $0(N=436)$ & 2010 & [42] \\
\hline Iran & $\begin{array}{l}\text { Hot desert with Mediterranean and } \\
\text { continental hot summer climate } \\
\text { in the north }\end{array}$ & $4.86 \%(N=453)$ & $N A^{d}$ & 2016 & {$[37]$} \\
\hline Nigeria & $\begin{array}{l}\text { Tropical Savanna climate with hot } \\
\text { semi-arid climate in the north }\end{array}$ & $10.6 \%(N=199)$ & NA & 2012 & {$[40]$} \\
\hline Nigeria & $\begin{array}{l}\text { Tropical savanna climate with hot } \\
\text { semi-arid climate in the north }\end{array}$ & $1.25 \%(N=960)$ & NA & 2015 & [36] \\
\hline Nigeria & $\begin{array}{l}\text { Tropical savanna climate with hot } \\
\text { semi-arid climate in the north }\end{array}$ & $\begin{array}{l}2 \%(N=1130)(\text { Taenia/Echinococ- } \\
\text { cus })\end{array}$ & NA & 2012 & {$[35]$} \\
\hline Pakistan & $\begin{array}{l}\text { Hot desert with hot semi-arid } \\
\text { climate in the north }\end{array}$ & $2.7 \%(N=520)$ & NA & 2017 & [39] \\
\hline Turkey & $\begin{array}{l}\text { Mixed cold semi-arid, Mediter- } \\
\text { ranean and continental hot sum- } \\
\text { mer climate }\end{array}$ & $3.5 \%(N=203)$ & $0(N=406)$ & 2005 & [84] \\
\hline Turkey & $\begin{array}{l}\text { Mixed cold semi-arid, Mediter- } \\
\text { ranean and continental hot sum- } \\
\text { mer climate }\end{array}$ & $\begin{array}{l}2.7 \%(N=111)(\text { Taenia/Echinococ- } \\
\quad \text { cus })\end{array}$ & NA & 2013 & [103] \\
\hline Jordan & Hot desert & $6 \%(N=133)$ & NA & 2016 & {$[38]$} \\
\hline Saudi Arabia & Hot desert & $\begin{array}{l}3.2 \%(N=470)(\text { Taenia/Echinococ- } \\
\text { cus) }\end{array}$ & NA & 2010 & {$[44]$} \\
\hline Vietnam & Tropical savanna climate & $<1 \%(N=317)$ & NA & 2009 & [43] \\
\hline Libya & Hot desert & $\begin{array}{l}\text { Taenia/Echinococcus spp.: in } 6 \% \text { of } \\
\text { tomato }(N=36), 25 \% \text { of cucum- } \\
\text { ber }(N=36), 33 \% \text { of lettuce ( } N \\
=27) \text { and } 30 \% \text { of cress samples } \\
(N=27)\end{array}$ & NA & 2010 & [83] \\
\hline
\end{tabular}

\footnotetext{
a Köppen climate classification

b Immersed in tap water in sink for 6-7 min, then, rinsed for 1.5-2 mins

c Washed, immersed in solution containing 200 ppm active calcium hypochlorite for $30 \mathrm{mins}$, rinsed in automated fruit-vegetable washer.

${ }^{d}$ Not applicable, not investigated in the study
} 
Eleven papers reported on egg presence in soil and water samples (Table 3). Again, most articles focussed on all parasitic material found, and the results for Taenia spp. eggs were only a small part of the total results. In general, prevalence ranged from 0 to $43 \%$.

Invertebrates are considered to be possible vectors for the spread of parasitic eggs. In Thailand, one of 820 cockroaches collected in open-air shopping markets in Thailand carried a Taenia spp. egg [46], while in Peru, out of 54 pools of 309 wild-caught Aphodius spp. beetles, two were positive for T. solium, three were positive for $T$. hydatigena and two were positive for other taeniid eggs [47]. In two studies carried out in Mexico, on the other hand, none of the 600 [48) and 1187 [49] flies caught in kitchens carried Taenia spp. eggs in their gut.

To confirm the possibility that an invertebrate species might carry and disseminate eggs in the environment, eggs have been fed to selected species in laboratory experiments. Beetles (Pterostichus vulgaris, Aphodius fimetarius, A. luridus, Ammophorus rubripes), flies (Calliphora quadromaculata, C. hortona, C. stygia) and earthworms (Eisenia foulida, Lumbricus terrestris and Allolobophora caliginosa) fed with Taenia spp. eggs were found to contain eggs in the digestive tract after dissection [19, 50-52]. When beetles (Ammophorus rubripes) and blowflies (Hybopygia varia, Calliphora quadromaculata, C. hortona and C. stygia) infected in the laboratory with Taenia spp. eggs were fed to pigs and lambs, respectively, $94.4 \%$ of pigs presented with cysticercosis and all blowflies had transferred the infection $[19,53]$.

Lawson and Gemmell [19, 20, 54-56] performed several experiments to determine the possible infection route via invertebrates and dispersal in the field. Lambs that were allowed to graze downwind of dog kennels or in close proximity to a plot where infected dogs had been previously kept contained a much higher level of cysticerci, detected during autopsy, than those grazing elsewhere. Dead blowflies containing eggs of T. hydatigena spread on a pasture were able to transmit infection if ingested by lambs (70\% of 14 lambs infected). In another experiment, blowflies were first exposed to $T$. pisiformis eggs by contact with faeces from infected dogs and then afterwards given access to pasture. Five of eight rabbits subsequently allowed to graze on this pasture became infected. In a similar experiment, blowflies were allowed to come into contact with dog faeces contaminated with $T$. hydatigena eggs before they had access to meat. This meat was subsequently fed to pigs, and $100 \%$ of the pigs became infected. On the other hand, in experiments where human faeces containing $T$. saginata eggs were deposited $1.5 \mathrm{~m}$ from a pasture where calves were grazing, none of the calves contained cysticerci after 8 to 10 weeks [57]. On the Scottish island of St. Kilda, sheep were found to be commonly infected with T. hydatigena despite the absence of definitive hosts for this species. Torgerson et al. $[58,59]$ concluded that eggs had been transported by insects or birds from the nearest inhabited land mass $60 \mathrm{~km}$ further away. Lawson and Gemmell [19] also investigated the role of wind in the dispersal of eggs. Faecal samples contaminated with T. pisiformis eggs were placed in front of a fan and trays were placed to capture whatever was moved by the draft. The sediment was fed to rabbits, but none became infected.

Evidence for transmission between intermediate hosts does exist. In one experiment, pigs fed with proglottids of T. solium were placed among naïve pigs [60]. In each of the four trials, at least one of the naïve pigs became infected, but with much lower cyst intensities compared to the primarily infected pigs. Whether secondary infection was attributable to coprophagic habits is yet to be demonstrated.

\section{Sewage treatment and surface water}

A number of authors have linked access to surface water with a higher risk for cysticercosis, suggesting that eggs either end up in the surface water directly or as they pass through water treatment systems. Kyvsgaard et al. [61] found that allowing cattle access to drink from streams in Denmark was a major risk factor for bovine cysticercosis. Boone et al. [62] reported that the flooding of pastures, free access of cattle to surface water and proximity of wastewater effluent were explanatory variables for bovine cysticercosis in Belgium. In Brazil, the water source from rivers or streams was determined to be the main risk factor for bovine cysticercosis in multiple farms [63]. The flooding of agricultural land and grassland has also been associated with human and porcine cysticercosis in Kenya [64].

Several studies have shown that wastewater treatment plants are not fully capable of removing helminth eggs, including those of Taenia spp., from water (Table 4).

Newton et al. [65] laboratory tested different treatment processes for their ability to remove T. saginata eggs from wastewater. A sedimentation test showed that removal varied from 51 to $98 \%$ after 15 and 120 min, respectively. Sand filtration was able to remove $99.6 \%$ of eggs from the wastewater and a trickling filter could removed $62-70 \%$.

Eggs that are removed from wastewater in wastewater treatment systems are deposited in the sewage sludge that is formed during the process. Using untreated sludge to fertilize crops and pasture will therefore lead to a higher risk. Several studies have reported that some types of sludge treatment are inadequate in terms of inactivating taeniid eggs (Table 5).

In a study by Ilsøe et al. [66] that was carried out following several outbreaks of bovine cysticercosis in 


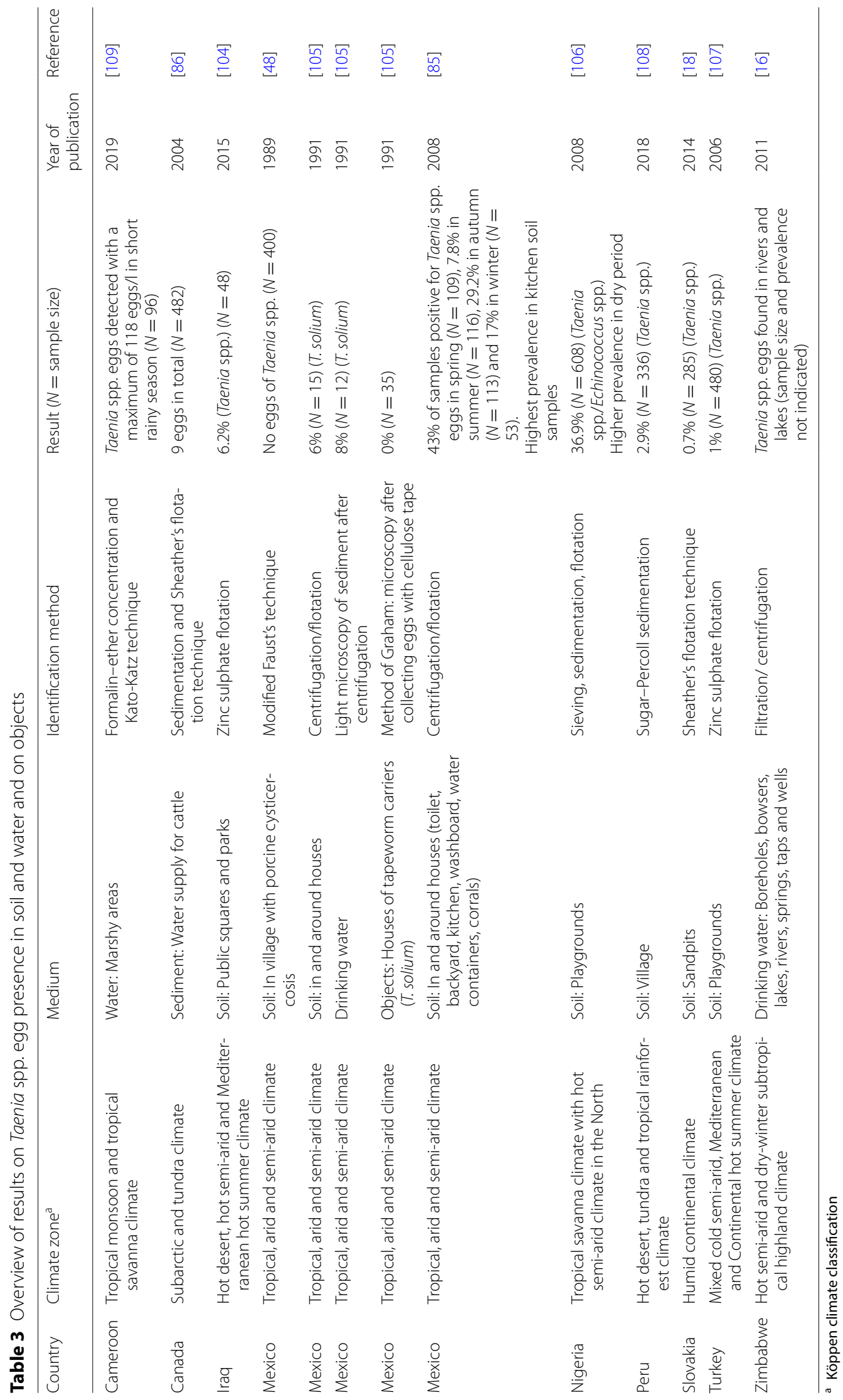


Table 4 Overview of results on Taenia spp. egg presence in the influent/effluent of wastewater treatment systems.

\begin{tabular}{|c|c|c|c|c|c|c|}
\hline Country & $\begin{array}{l}\text { Wastewater treatment } \\
\text { system }\end{array}$ & Egg recovery & Influent & Effluent & $\begin{array}{l}\text { Year of } \\
\text { publication }\end{array}$ & Reference \\
\hline Morocco & $\begin{array}{l}\text { Activated sludge and } \\
\text { natural lagoon }\end{array}$ & $\begin{array}{l}\text { Modified Bailenger } \\
\text { method (sedimentation, } \\
\text { centrifugation, flotation } \\
\text { and McMaster) }\end{array}$ & $\begin{array}{l}5.28 \mathrm{eggs} / \mathrm{l}(N=6) \text { and } 0 \\
\quad \mathrm{eggs} / \mathrm{L}(N=6)\end{array}$ & $\begin{array}{l}0 \text { eggs } / /(N=6) \text { and } 0 \\
\text { eggs/L }(N=6)\end{array}$ & 2018 & [110] \\
\hline Colombia & $\begin{array}{l}\text { Series of anaerobic, facul- } \\
\text { tative and maturation } \\
\text { ponds }\end{array}$ & $\begin{array}{l}\text { Modified Bailenger } \\
\text { method }\end{array}$ & $\begin{array}{l}63 \text { helminth eggs/l (N } \\
\quad=8)\end{array}$ & 0 eggs/l $(N=8)$ & 2002 & [111] \\
\hline Iran & $\begin{array}{l}\text { Activated sludge } \\
\text { Natural lagoons }\end{array}$ & $\begin{array}{l}\text { Modified Bailenger } \\
\text { method }\end{array}$ & $\begin{array}{l}\text { Low number present in } 2 \\
\text { of } 8 \text { plants ( } 3 \text { and } 1.25 \\
\text { eggs } / \text { I) ( } N=16 / \text { plant })\end{array}$ & $<1$ egg/l ( $N=16 /$ plant $)$ & 2006 & [112] \\
\hline Morocco & Stabilization ponds & Bailenger method & 0.1 eggs $/ \mathrm{I}(N=48)$ & 0 eggs $/ /(N=48)$ & 2000 & [113] \\
\hline Tunisia & $\begin{array}{l}\text { Activated sludge } \\
\text { Stabilization ponds }\end{array}$ & Bailenger method & $\begin{array}{l}\text { From } 28 \text { to } 208 \text { eggs/l ( } N \\
\quad=174)\end{array}$ & $\begin{array}{l}\text { From } 17 \text { to } 52 \text { eggs/l ( } N \\
\quad=174)\end{array}$ & 2009 & {$[88]$} \\
\hline Colombia & Anaerobic biodigestors & $\begin{array}{l}\text { Filtration, sedimentation, } \\
\text { centrifugation and } \\
\text { recovery by Sheather } \\
\text { and McMaster method }\end{array}$ & $\begin{array}{l}\text { Eggs in } 10 \% \text { of samples } \\
\qquad(N=80)\end{array}$ & $\begin{array}{l}\text { Eggs in } 10 \% \text { of samples } \\
\qquad(N=80)\end{array}$ & 2012 & [114] \\
\hline $\begin{array}{l}\text { South } \\
\text { Africa and } \\
\text { Lesotho }\end{array}$ & $\begin{array}{l}\text { Centralized plant } \\
\text { Decentralized plant }\end{array}$ & $\begin{array}{l}\text { Sieving, sedimentation } \\
\text { and flotation }\end{array}$ & $\begin{array}{l}6.4-29.6 \mathrm{eggs} / \mathrm{l} \text { to } 2.3 \\
\text { eggs/l }(N=55)\end{array}$ & $\begin{array}{l}1.4 \text { to } 8.4 \mathrm{eggs} / \mathrm{l}-0.25 \\
\text { eggs/L }(N=55)\end{array}$ & 2018 & {$[87]$} \\
\hline Bolivia & $\begin{array}{l}\text { Facultative pond followed } \\
\text { by maturation pond }\end{array}$ & $\begin{array}{l}\text { Centrifugation, flotation } \\
\text { and biphasic separation }\end{array}$ & $306-3006$ eggs/l $(N=3)$ & 45 eggs $/ L(N=3)$ & 2013 & [115] \\
\hline Tunisia & $\begin{array}{l}\text { Activated sludge } \\
\text { Natural lagoons }\end{array}$ & $\begin{array}{l}\text { Modified Bailenger } \\
\text { method }\end{array}$ & $\begin{array}{l}\text { Taeniid eggs in } 85 \% \text { of } \\
\text { samples }(N=117)\end{array}$ & $\begin{array}{l}\text { Taeniid eggs in } 30 \% \text { of } \\
\text { samples }(N=117)\end{array}$ & 2018 & [89] \\
\hline
\end{tabular}

Denmark, illegal application of sludge from septic tanks onto pasture and crops was found to be a frequent source of infection. For livestock permanently housed indoors, the highest risk was fodder as feed (hay harvested from meadow fertilized with septic tank contents and fresh grass harvested after the end of the camping season on camping sites without adequate toilet facilities) or indoor contamination with slurry containing eggs [66]. Newton et al. [65] found that T. saginata eggs could survive for months in anaerobic sludge at room temperature; after 200 days, $10-15 \%$ of eggs still appeared normal. A study performed by Storey and Phillips [67] showed that eggs of T. saginata applied to pasture (in sewage sludge) could still be found on the soil surface after 200 days. Rainfall was able to wash the eggs into the soil where they were protected from radiation and desiccation.

Infectivity of eggs in sludge has been examined using test animals. Olsen and Nansen [68] submerged bags with eggs of T. taeniaeformis in sewage sludge of a mesophilic anaerobic batch digester at $35^{\circ} \mathrm{C}$, following which these eggs were placed in mice by an intragastric procedure; cyst recovery declined from 25 to $2 \%$ after only 2 days. In Australia, groups of 40 cattle were allowed to graze on pastures irrigated with raw sewage and effluent from lagooning processes, trickling filter plants and activated sludge plants; $30,3.3,9$ and $12.5 \%$ of the animals were found to be infected [69]. In France, however, no cysticerci were found in the heart, masseter muscle, diaphragm and tongue of the cattle that had been allowed to graze on fields to which liquid sewage sludge containing 2.5-4.4 T. saginata eggs/g of dry matter had been applied [70]. Control animals that were fed the sludge directly had 1-4 cysticerci in these four body parts. The authors concluded that a 6-week delay between fertilization and grazing was sufficient to inactivate $T$. saginata eggs. A caveat to this study is that low infections are likely to be missed by only dissecting four body parts [70]. In a similar experiment, sheep that were grazing on pasture fertilized with sewage sludge or cattle slurry containing Taenia spp. eggs were not infected; however, sheep are not the natural hosts of T. saginata, so the result on Taenia spp. should be assessed with caution [71].

\section{Discussion}

The results summarized in the review show that as a general rule humidity seems to affect Taenia spp. egg survival more than temperature, with low humidity hampering survival $(<34 \%)$ [72]. Moderate temperatures $\left(5-25^{\circ} \mathrm{C}\right)$ favour survival [73, 75], while warmer temperatures $\left(>25^{\circ} \mathrm{C}\right)$ shorten survival time $[74,76]$, as does freezing [77]. Under field conditions, Taenia spp. eggs can survive for at least 1 year, as demonstrated by Duthy et al. [28] on Kenyan pastures (T. saginata). Other Taenia spp. have been shown to survive outdoors for a shorter 


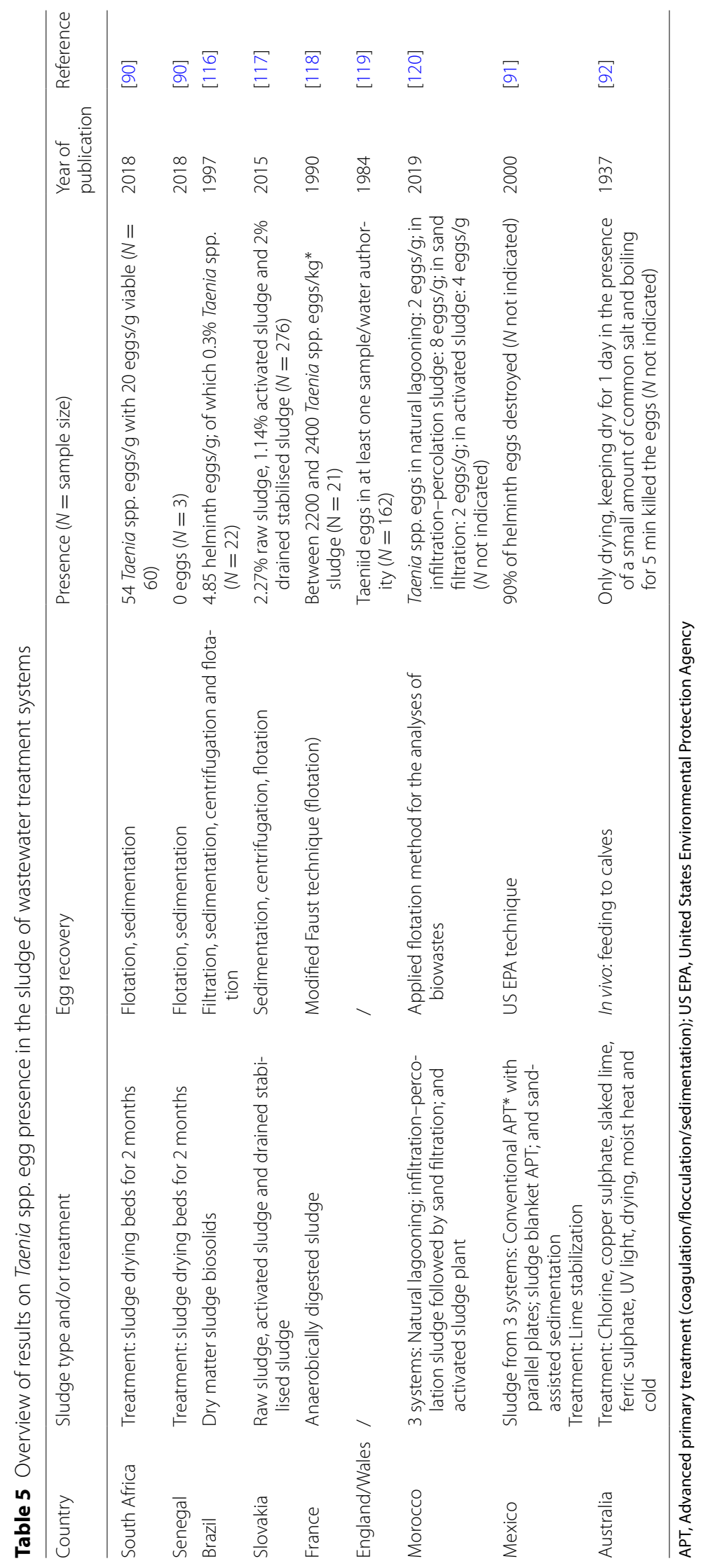


time period (T. multiceps, Wales, [75]), suggesting that survival is dependent on the Taenia spp. studied and the outdoor conditions. Since most of the studies included in this review covered only a limited time period and given current knowledge that eggs are able to survive for at least 1 year, the fact that many studies still found eggs to survive at the end of the study period does not allow a solid conclusion to be made on when survival will have decreased to a minimum [73, 76, 78]. The long survival time, certainly under optimal conditions, inevidently increases the chance for an egg to infect a new host and transmit the infection.

The studies retrieved during the literature search mostly describe experiments on egg survival in Taenia spp. other than T. saginata, T. asiatica and T. solium. The eggs of these other Taenia spp. might be affected in a similar way when put under stress although this is not a certainty; for example, eggs of Echinococcus granulosus, which are morphologically identical to those of Taenia spp. were still infective after freezing to $-30^{\circ} \mathrm{C}$ [79].

Several in vivo experiments included in this review reported questionable results due to the unknown prior infection status of the experimental animals (e.g. [28]), unknown prior infectivity status of the pasture or the absence of a control for natural infection occurring during the experiment (e.g. [28]). In other experiments, a small sample size was often reported (e.g. [80]). Experiments using in vivo techniques, detecting cysticerci in test animals, may be biased because the establishment of cysticerci is highly variable among individual animals [81]. Coman and Rickard [26] found that in vitro techniques for assessing the hatching and viability of T. pisiformis eggs did not reliably agree with their infectivity in rabbits, indicating that it may not be possible to compare results from studies using in vitro and in vivo techniques.

There is a lack of recent, structured research on the environmental factors affecting egg survival of the zoonotic Taenia spp. Studies on this topic can be complicated by the accessibility of Taenia spp. eggs for experimental work. To be able to compare results, homogenous batches of eggs are necessary, but developmental stages and egg infectivity are highly variable between individual tapeworms, between proglottids from the same tapeworm and even within one proglottid [82]. In addition, laboratory extraction and preparation processes may affect the viability of eggs. It should also be noted that working with eggs of T. solium is highly hazardous. As a proxy for studies on the survival of eggs of zoonotic Taenia spp., eggs of non-zoonotic Taenia spp. may be used, which are easier to obtain and do not pose a health hazard in the laboratory. However, although eggs of Taenia spp. are morphologically undistinguishable, their resistance to environmental conditions may differ. It is important to obtain species-specific data which may help inform dynamic transmission models for the zoonotic Taenia spp. An understanding of the distribution of egg survival times under different conditions would help setting-specific parameterization and greatly facilitate modelling.

The prevalence of Taenia spp. eggs found on fruits and vegetables is high, ranging from 0.9 to $33 \%[41,83]$. These studies were mostly conducted in developing countries where environmental contamination is expected to be higher due to inadequate sanitary practices. The risk for infection in these countries is therefore most likely higher than in Europe, although in Europe Taenia spp. DNA was found on up to $28 \%$ of samples (purchased from fields, greenhouses and wholesalers) in the spring [17]. After industrial washing, the prevalence is greatly reduced, although little information is available on this subject $[41,45,84]$. Overall, there is a risk for infection for the consumer. Industrial washing is performed using active calcium hypochlorite; regular washing with water might not sufficiently reduce the risk.

In soil and water samples, prevalence ranges from 0 to $43 \%[48,85]$. Studies analysing soil and water samples were performed in a more varied selection of countries. However, similar to the literature regarding parasite egg prevalence on fruits and vegetables, these articles generally focussed on parasite eggs other than those of Taenia spp.; as such, the information available is limited. It has also been shown that egg recovery from vegetables, fruits and the environment (soil and water) was low [86], which may have resulted in underestimation of the data.

Variable survival and initial parasite loads on fruit and vegetables and in the soil and water might be found in other climate zones that are not represented in our review. Hygienic standards could vary significantly among regions, and results may not be relevant for other regions. Contamination of fruits and vegetables could happen at any stage during the transit from the field (where the crop was fertilized) to the processing. Poor personal hygiene and general unsanitary conditions could lead to post-washing contamination and hence transmission [36].

Although there is a good body of information showing that eggs can spread and even infect animals through invertebrates in experimental settings, it remains unclear how likely and how important these scenarios could be in real-life settings. Only four articles considered the parasite egg load of insects caught in the wild, and prevalence in these studies was low.

An important factor in the spread and survival of parasitic eggs is the wastewater treatment system. As seen from the results shown here, egg removal efficiency is very variable in the different systems used in different 
countries, and many systems were found to be unable to fully remove Taenia spp. eggs from the treatment water [87-89], allowing the eggs to spread over larger distances via waterways. As egg survival is determined by humidity, eggs are able to survive in water for a long time. Furthermore, several articles pinpointed access to surface water or the proximity of a wastewater treatment plant as risk factors for cysticercosis [61-63].

The inability to remove Taenia spp. eggs from the wastewater may be due to the type of wastewater treatment system and its quality. The variability between systems and between parasite egg load in the influent make it difficult to project these results to other regions and wastewater management systems. The papers also focussed on total parasite egg load and provided only limited information on Taenia spp.

Most of the eggs end up in the sewage sludge produced during the processing of wastewater [90-92], and experiments have proven that eggs can remain viable for a long time, retaining their infectivity for hosts and thus potentially leading to outbreaks [66-69]. Therefore, using sludge from wastewater treatment plants to fertilize fields on which crops used for animal fodder and human food are subsequently grown could lead to a very high risk of infection. In the EU, the use of sewage sludge in agriculture on land grazed by cattle is restricted and regulated under Council Directive 86/278/EEC [93]. In general, the Directive states that sludge can be used, albeit under conditions in which harmful effects are prevented to soil, vegetation, animals and humans. Sludge must be treated prior to its application on fields by either injecting or working into the soil. In terms of the risk of Taenia spp. eggs, there needs to be a minimum of 3 weeks of no grazing or harvesting of crops after treatment with sludge. As it has been demonstrated that eggs remain viable up to 1 year, this period is clearly too short. Some EU countries, however, have a more stringent national legislation compared to the EU directive (Austria, Belgium, Denmark, France, Germany, Netherlands, Sweden) [94].

\section{Conclusions}

In conclusion, the results of this systematic review show that our knowledge of the survival and transmission of Taenia spp. eggs in the environment is limited. Indeed, in terms of factors determining egg survival, the results were often doubtful, and in terms of contamination of food, soil, water and the water and sludge from the sewage treatment process, the information was focussed on specific regions (climate zones) or was not specific for Taenia spp. Current results indicate that egg survival at moderate temperatures $\left(5-25^{\circ} \mathrm{C}\right)$, combined with other conditions favourable for survival (e.g. $\mathrm{RH}>80 \%$ ), together with the large number of factors facilitating egg dispersal (ineffective sewage treatment, contamination of food, possible dispersal in water and soil and to some extent transmission by invertebrates) are making future control/elimination of Taenia spp. challenging. Future studies are necessary to identify applicable and sustainable methods to identify and inactivate parasite eggs in the environment and to reduce the spread thereof. Molecular techniques, such as the use of microsatellite markers, to examine genetic variability at the farm or regional level may help unravel specific knowledge gaps. Understanding the epidemiology and the transmission dynamics of Taenia spp., and thus approaching egg survival and the dispersal problem from a different angle, might result in new insights and lead to other, possibly more efficient control options.

\section{Supplementary Information}

The online version contains supplementary material available at https://doi. org/10.1186/s13071-021-04589-6.

Additional file 1: The protocol used for this review.

Additional file 2: PRISMA checklist.

Acknowledgements

We would like to thank all the members of the European Network on Taeniosis/Cysticercosis (CYSTINET, COST Action TD1302).

\section{Author's contributions}

All authors (FJ, PD, SG, VD, MVJ, CT) contributed to the conception and design of the review. The systematic review was performed by FJ and CT, and development of the manuscript was mainly the responsibility of FJ, with the help of CT. All authors contributed to the changes made to subsequent versions from the first version onwards. All authors read and approved the final manuscript.

Funding

Not applicable.

Availability of data and materials

Not applicable.

Ethics approval and consent to participate Not applicable.

Consent for publication

Not applicable.

\section{Competing interests}

The authors declare that they have no competing interests.

\section{Author details}

${ }^{1}$ Department of Biomedical Sciences, Institute of Tropical Medicine, 155 Nationalestraat, 2000 Antwerp, Belgium. ${ }^{2}$ Department of Veterinary Public Health and Food Safety, Faculty of Veterinary Medicine, Ghent University, 133 Salisburylaan, 9820 Merelbeke, Belgium. ${ }^{3}$ Department of Veterinary and Animal Sciences, Faculty of Health and Medical Sciences, University of Copenhagen, 100 Dyrlægevej, 1870 Frederiksberg, Denmark.

Received: 12 August 2020 Accepted: 8 January 2021

Published online: 29 January 2021 


\section{References}

1. Jansen F, Dorny P, Trevisan C, Dermauw V, Laranjo-González M, Allepuz $A$, et al. Economic impact of bovine cysticercosis and taeniosis caused by Taenia saginata in Belgium. Parasites Vectors. 2018;11:241.

2. Laranjo-González M, Devleesschauwer B, Jansen F, Dorny P, Dupuy C, Polack $B$, et al. Epidemiology and economic impact of bovine cysticercosis and taeniosis caused by Taenia saginata in North-Eastern Spain (Catalonia). Parasites Vectors. 2018;11:376.

3. World Health Organization. Murrell K, editor; Dorny P, Flisser A, Geerts S, Kyvsgaard NC, McManus D, et al., associate editors. WHO/FAO/OIE guidelines for the surveillance, prevention and control of taeniosis/ cysticercosis. Geneva: WHO/FAO/OIE; 2005.

4. Eom K. What is Asian Taenia? Parasitol Int. 2006;55:137-41.

5. Craig P, Ito A. Intestinal cestodes. Curr Opin Infect Dis. 2007;20:524-32.

6. Garcia HH, Gonzalez AE, Evans CAW, Gilman RH. Taenia solium cysticercosis. Lancet. 2003:362:547-56.

7. World Health Organization. Ending the neglect to attain the Sustainable Development Goals — a road map for neglected tropical diseases 2021-2030. Geneva: World Health Organization; 2020.

8. Gripper LB, Welburn SC. The causal relationship between neurocysticercosis infection and the development of epilepsy — a systematic review. Infect Dis Poverty. 2017:6:31.

9. Ndimubanzi PC, Carabin H, Budke CM, Nguyen H, Qian Y-J, Rainwater E, et al. A systematic review of the frequency of neurocyticercosis with a focus on people with epilepsy. PLoS NegI Trop Dis. 2010;2(4):e870.

10. Dorny P, Praet N. Taenia saginata in Europe. Vet Parasitol. 2007;149:22-4.

11. Laranjo-González M, Devleesschauwer B, Gabriël S, Dorny P, Allepuz A Epidemiology, impact and control of bovine cysticercosis in Europe: a systematic review. Parasites Vectors. 2016;9:81.

12. Uygyr-Bayramicli O, Ak O, Dabak R, Demirhan G, Ozer S. Taenia saginata a rare cause of acute cholangitis: a case report. Acta Clin Belg. 2012:67:436-7.

13. Bekraki A, Hanna K. Peritonitis caused by jejunal perforation with Taenia saginata: report of a case. J Parasit Dis. 2016;40:203-4.

14. Najih M, Laraqui H, Njoumi N, Mouhafid F, Moujahid M, Ehirchiou A, Zentar A. Taenia saginata: an unusual cause of post-appendectomy faecal fistula. Pan Afr Med J. 2016;25:200.

15. Arriola CS, Gonzalez AE, Gomez-Puerta LA, Lopez-Urbina MT, Garcia HH, Gilman RH. New insights in cysticercosis transmission. PLoS Negl Trop Dis. 2014;8:e3247.

16. Dalu T, Barson M, Nhiwatiwa T. Impact of intestinal microorganisms and protozoan parasites on drinking water quality in Harare. Zimbabwe J Water Sanit Hyg Develop. 2011;3:153-63.

17. Federer K, Armua-Fernandez MT, Gori F, Hoby S, Wenker C. Deplazes P. Detection of taeniid (Taenia spp., Echinococcus spp.) eggs contaminat ing vegetables and fruits sold in European markets and the risk for metacestode infections in captive primates. Int J Parasitol Parasites Wildl. 2016; 5: 249-53.

18. Papajova I, Pipikova J, Papaj J, Cizmar A. Parasitic contamination of urban and rural environments in the Slovak Republic: dog's excrements as a source. Helminthologia. 2014;51:273-80.

19. Lawson JR, Gemmell MA. The potential role of blowflies in the transmission of taeniid tapeworm eggs. Parasitology. 1985;91:129-43.

20. Lawson JR, Gemmell MA. Transmission of taeniid tapeworm eggs via blowflies to intermediate hosts. Parasitology. 1990;100:143-6.

21. Gabriël S, Dorny P, Mwape KE, Trevisan C, Braae UC, Magnussen P, et al. Control of Taenia Solium taeniasis/cysticercosis: The best way forward for sub-Saharan Africa? Acta Trop. 2017; 165: 252-60.

22. Pawlowski Z. Basic biology and transmission. In: Singh G, editor. Taenia solium cysticercosis from basic to clinical science. London: CAB International; 2002. p. 1-13.

23. Brandt JRA, Sewell MMH. In vitro hatching and activation of Taenia taeniaeformis oncospheres. Vet Res Commun. 1981;5:193-9.

24. Silverman PH. Studies on the biology of some tapeworms of the genus Taenia. I. Factors affecting hatching and activation of taeniid ova, and some criteria of their viability. Ann Trop Med Parasitol. 1954;48:207-15.

25. Wang IC, Ma YX, Kuo CH, Fan PC. A comparative study on egg hatching methods and oncosphere viability determination for Taenia solium eggs. Int J Parasitol. 1997;27:1311-4.

26. Coman BJ, Rickard MD. A comparison of in vitro and in vivo estimates of the viability of Taenia pisiformis eggs aged under controlled conditions, and their ability to immunize against a challenge infection. Int J Parasitol. 1977;7:15-20.

27. Moher D, Liberati A, Tetzlaff J, Altman DG, PRISMA Group. Preferred reporting items for systematic reviews and meta-analyses: The PRISMA statement. PLoS Med. 2009;6:e1000097.

28. Duthy $B L$, van Someren VD. The survival of Taenia saginata on open pasture. East Afr Agri J. 1948:13:147-8

29. Araújo JM, Araújo JV, Braga FR, Carvalho RO, Silva AR, Campos AK. Interaction and ovicidal activity of nematophagous fungus Pochonia chlamydosporia on Taenia saginata eggs. Exp Parasitol. 2009; 121: 338-41.

30. Araújo JM, Braga FR, Araújo JV, Soares FEF, Geniêr HLA. Biological control of Taenia saginata eggs. Helminthologia. 2010;47:189-92.

31. Braga FR, Araújo JV, Carvalho RO, Silva AR, Araújo JM, Tavela AO, et al. Ovicidal effect of nemathophagous fungi on Taenia taeniaeformis eggs. World J Microbiol Biotechnol. 2009;25:533-5.

32. Braga FR, Silva AR, Carvalho RO, Araújo JV, Pinto PSA. Ovicidal activity of different concentrations of Pochonia chlamydosporia chlamydospores on Taenia taeniaeformis eggs. J Helminthol. 2011;85:7-11.

33. Ciarmela ML, Thevenet PS, Alvarez HM, Minvielle MC, Basualdo JA. Effect of Paecilomyces lilacinus on the viability of oncospheres of Taenia hydatigena. Vet Parasitol. 2005;131:61-4.

34. Prokopič J, Jelenová I. Effect of fertilizers on Taenia saginata Goeze, 1782 egg viability in vitro. Folia Parasitol. 1980;27:343-7.

35. Adamu NB, Adamu JY, Mohammed D. Prevalence of helminth parasites found on vegetables sold in Maiduguri. Northeastern Nigeria Food Control. 2012:25:23-6.

36. Adenusi AA, Abimbola WA, Adewoga TOS. Human intestinal helminth contamination in pre-washed, fresh vegetables for sale in major markets in Ogun state, southwest Nigeria. Food Control. 2015;50:843-9.

37. Fallah AA, Makhtumi Y, Pirali-Kheirabadi K. Seasonal study of parasitic contamination in fresh salad vegetables marketed in Shahrekord. Iran Food Control. 2016;60:538-42.

38. Ismail Y. Prevalence of parasitic contamination in salad vegetables collected from supermarkets and street vendors in Amman and Baqa'aJordan. Pol J Microbiol. 2016:65:201-7.

39. Khan W, Mumtaz G, Bibi S, Afzal S. Parasitic contamination of fresh vegetables sold at upper and lower Dir districts, Khyber Pakhtunkhwa, Pakistan. Pak J Zool. 2017;49:1115-8.

40. Maikai BV, Elisha IA, Baba-Onoja EBT. Contamination of vegetables sold in markets with helminth eggs in Zaria metropolis, Kaduna state. Nigeria Food Control. 2012:28:345-8.

41. Rostami A, Ebrahimi M, Mehravar S, Omrani VF, Fallahi S, Behniafar $H$. Contamination of commonly consumed raw vegetables with soil transmitted helminth eggs in Mazadaran province, northern Iran. Int J Food Microbiol. 2016;225:54-8.

42. Shahnazi M, Jafari-Sabet M. Prevalence of parasitic contamination of raw vegetables in villages of Qazvin province. Iran Foodborne Pathog Dis. 2010;7:1025-30.

43. Uga S, Hoa NTV, Noda S, Moji K, Cong L, Aoki Y, et al. Parasite egg contamination of vegetables from a suburban market in Hanoi. Vietnam Nep Med Coll J. 2009;11:75-8.

44. Al-Megrin WAl. Prevalence intestinal parasites in leafy vegetables in Riyadh. Saudi Arabia Int J Trop Med. 2010;5:20-3.

45. Fallah AA, Pirali-Kheirabadi K, Shirvani F, Saei-Dehkordi SS. Prevalence of parasitic contamination in vegetables used for raw consumption in Shahrekord, Iran: influence of season and washing procedure. Food Control. 2012;25:617-20.

46. Chamavit P, SahaisookT, Niamnuy N. The majority of cockroaches from the Samutprakarn province of Thailand are carriers of parasitic organisms. EXCLI J. 2011;10:218-22.

47. Vargas-Calla A, Gomez-Puerta LA, Pajuelo MJ, Garcia HH, Gonzalez AE. for the cysticercosis working group in Peru. Molecular detection of taeniid eggs in beetles collected in an area endemic for Taenia solium. Am J Trop Med Hyg. 2018;99:1198-200.

48. Keilbach NM, de Aluja AS, Sarti-Gutierrez E. A programme to control taeniasis-cysticercosis (T. solium): experiences in a Mexican village. Acta Leidensia. 1989:57:181-9.

49. Martinez MJ, De Aluja AS, Gemmell M. Failure to incrimate domestic flies (Diptera: Muscidae) as mechanical vectors of Taenia eggs (Cyclophyllidae: Taeniidae) in rural Mexico. J Med Entomol. 2000;37:489-91. 
50. Bily S, Sterba J, Dykova I. Results of an artificial feeding of eggs of Taenia saginata Goeze, 1782 to various beetle species. Folia Parasitol. 1978;25:257-69.

51. Gomez-Puerta LA, Lopez-Urbina MT, Garcia HH, Gonzalez AE. Longevity and viability of Taenia solium eggs in the digestive system of the beetle Ammophorus rubripes. Rev Bras Parasitol Vet. 2014;23:94-7.

52. Lonc $E$. The possible role of the soil fauna in the epizootiology of cysticercosis in cattle. I. Earthworms - the biotic factor in a transmission of Taenia saginata eggs. Angew Parasitol. 1980;21:133-9.

53. Gomez-Puerta LA, Garcia HH, Gonzalez AE. for the cysticercosis working group in Peru. Experimental porcine cysticercosis using infected beetles with Taenia solium eggs. Acta Trop. 2018;183:92-4.

54. Gemmell MA, Macnamara FN. Factors regulating tapeworm populations: estimations of the infection pressure and index of clustering from Taenia hydatigena before and after the removal of infected dogs. Res Vet Sci. 1976;21:215-9.

55. Gemmell MA. Factors regulating tapeworm populations: estimations of the build-up and dispersion patterns of eggs after the introduction of dogs infected with Taenia hydatigena. Res Vet Sci. 1976;21:220-2.

56. Gemmell MA, Johnstone PD, Boswell CC. Factors regulating tapeworm populations: dispersion patterns of Taenia hydatigena eggs on pasture. Res Vet Sci. 1978;24:334-8.

57. Kyvsgaard NC, Ilsoe B, Henriksen SA, Nansen P. An attempt to evaluate the spreading of Taenia saginata eggs in the environment. Acta Vet Scand. 1988;29:511-3.

58. Torgerson PR, Gulland FMD, Gemmell MA. Observations on the epidemiology of Taenia hydatigena in Soay sheep on St Kilda. Vet Rec. 1992;131:218-9.

59. Torgerson PR, Pilkington J, Gulland FMD, Gemmell MA. Further evidence for the long-distance dispersal of Taeniid eggs. Int J Parasitol. 1995;25:265-7.

60. Gonzalez AE, LopezUrbina T, Tsang BY, Gavidia CM, Garcia HH. the cysticercosis working group Peru. Short report: secondary transmission in porcine cysticersosis: description and their potential implications for control sustainability. Am J Trop Hyg. 2005;73:501-3.

61. Kyvsgaard NC, Ilsoe B, Willeberg P, Nansen P, Henriksen SA. A casecontrol study of risk factors in light of Taenia saginata cysticercosis in Danish cattle. Acta Vet Scand. 1991;32:243-52.

62. Boone I, Thys E, Marcotty T, de Borchgrave J, Ducheyne E, Dorny P. Distribution and risk factors of bovine cysticercosis in Belgian dairy and mixed herds. Prev Vet Med. 2007:82:1-11.

63. Duarte CTD, Pinto PSA, Silva LF, Santos TO, Bevilacqua PD, Nieto ECA. Epidemiological aspects of cysticercoses in relation to hydrographic net at Triangulo Mineiro, MG, Brazil. Semina: Ciências Agrárias. 2018;39:221-30.

64. Wardrop NA, Thomas LF, Atkinson PM, de Glanville WA, Cook EAJ, et al. The influence of socio-ecnomic, behavioural and environmental factors on Taenia spp. transmission in Western Kenya: evidence from a cross-sectional survey in humans and pigs. PLoS Negl Trop Dis. 2015:9:e0004223.

65. Newton WL, Bennett HJ, Figgat WB. Observations on the effect of various sewage treatment processes upon eggs of Taenia saginata. Am J Hyg. 1949;49:166-75.

66. Ilsoe B, Kyvsgaard NC, Nansen P, Henriksen SA. Bovine cysticercosis in Denmark: a study of possible causes of infection in farms with heavily infected animals. Acta Vet Scand. 1990;31:159-68.

67. Storey GW, Philips RA. The survival of parasite eggs throughout the soil profile. Parasitology. 1985;91:585-90.

68. Olsen JE, Nansen P. Infectivity of eggs of Taenia taeniaeformis after anaerobic digestion of sewage sludge-a possible model for Taenia saginata egg resistance. Acta vet Scand. 1990;31:377-9.

69. Arundel JH, Adolph AJ. Preliminary observations on the removal of Taenia saginata eggs from sewage using various treatment processes. Aust Vet J. 1980;56:492-5.

70. Moussavou-Boussougou MN, Geerts S, Madeline M, Ballandonne C Barbier D, Cabaret J. Sewage sludge or cattle slurry as pasture fertilisers: comparative cysticersosis and trichostrongylosis risk for grazing cattle. Parasitol Res. 2005;97:27-32.
71. Moussavou-Boussougou MN, Dorny P, Cabaret J. Very low helminth infection in sheep grazed on pastures fertilised by sewage sludge or cattle slurry. Vet Parasitol. 2005;131:65-70.

72. Laws GF. Physical factors influencing survival of taeniid eggs. Exp Parasitol. 1968;22:227-39.

73. Froyd G. Longevity of Taenia saginata eggs. J Parasitol. 1962;48:279.

74. Gemmell MA. Taeniidae: Modification to the life span or the egg and the regulation of tapeworm populations. Exp Parasitol. 1977;41:314-28.

75. Willis JM, Herbert IV. Some factors affecting the eggs of Taenia multiceps: their transmission onto pasture and their viability. Ann Trop Med Parasit. 1984;78:236-42.

76. Coman BJ. The survival of Taenia pisiformis eggs under laboratory conditions and in the field environment. Aust Vet J. 1975;51:560-5.

77. Lucker JT. A test of resistance of Taenia saginata eggs to freezing. J Parasitol. 1960;46:304.

78. Bucur I, Gabriël S, Van Damme I, Dorny P, Johansen MV. Survival of Taenia saginata eggs under different environmental conditions. Vet Parasitol. 2019;266:88-95.

79. Colli CW, Williams JF. Influence of temperature on the infectivity of eggs of Echinococcus granulosus in laboratory rodents. J Parasitol. 1972;58:422-6.

80. Ilsoe B, Kyvsgaard NC, Nansen P, Henriksen SA. A study on the survival of Taenia saginata eggs on soil in Denmark. Acta Vet Scand. 1990:31:153-8.

81. Deckers N, Kanobana K, Silva M, Gonzalez AE, Garcia HH, Gilman RH, et al. Serological responses in porcine cysticercosis: A link with the parasitological outcome of infection. Int J Parasitol. 2008;38:1191-8.

82. Geerts S. Taenia saginata: an eternal problem? Verh K Acad Geneeskd Belg. 1990;52:537-63.

83. Abougrain AK, Nahaisi MH, Madi NS, Saied MM, Ghenghesh KS. Parasitological contamination in salad vegetables in Tripoli, Libya. Food Control. 2010;21:760-2.

84. Kozan E, Gonenc B, Sarimehmetoglu O, Aycicek H. Prevalence of helminth eggs on raw vegetables used for salads. Food Control. 2005;16:239-42.

85. Huerta M, Avila R, Jiménez HI, Diaz R, Diaz Huerta ME, Hernandez M, et al. Parasite contamination of soil in households of a Mexican rural community endemic for neurocysticersosis. Trans R Soc Trop Med Hyg. 2008;102:374-9.

86. Scandrett WB, Gajadhar AA. Recovery of putative taeniid eggs from silt in water associated with an outbreak of bovine cysticercosis. Can Vet J. 2004:45:758-60.

87. Amoah ID, Reddy P, Seidu R, Stenstrom TA. Removal of helminth eggs by centralized and decentralized wastewater treatment plants in South Africa and Lesotho: health implications for direct and indirect exposure to the effluents. Environ Sci Pollut Res. 2018;25:12883-95.

88. Ben Ayed L, Schijven J, Alouini Z, Jemli M, Sabbahi S. Presence of parasitic protozoa and helminth in sewage and efficiency of sewage treatment in Tunisia. Parasitol Res. 2009;105:393-406.

89. Sabbahi S, Trad M, Ben Ayed L, Marzougui N. Occurrence of intestinal parasites in sewage samples and efficiency of wastewater treatment systems in Tunisia. Water Qual Res J. 2018;53:86-101.

90. Amoah ID, Reddy P, Seidu R, Stenstrom TA. Concentration of soiltransmitted helminth eggs in sludge from South-Africa and Senegal: a probabilistic estimation of infection risks associated with agricultural application. J Environ Manage. 2018;206:1020-7.

91. Jimenez B, Barrios JA, Maya C. Class B biosolids production from wastewater sludge with high pathogenic content generated in an advanced primary treatment. Water Sci Technol. 2000;42:103-10.

92. Penfold WJ, Penfold HB, Phillips M. The criteria of life and viability of mature Taenia saginata ova. Med J Aust. 1937;2:1-5.

93. European Economic Community. Council Directive 86/278/EEC of 12 June 1986 on the protection of the environment, and in particular of the soil, when sewage sludge is used in agriculture. Off J Euro Community. 1986:4:6e12.

94. European Commission. Disposal and recycling routes for sewage sludge. Part 2-regulatory report. Off J Euro Community. 2001. http:// ec.europa.eu/environment/archives/waste/sludge/pdf/sludge_dispo sal2.pdf. Accessed 20 May 2020 
95. Buttar BS, Nelson ML, Busboom JR, Hancock DD, Walsh DB, Jasmer DP. Effect of heat treatment on viability of Taenia hydatigena eggs. Exp Parasitol. 2013;133:421-6.

96. Thevenet PS, Alvarez HM, Basualdo JA. Survival, physical and physiological changes of Taenia hydatigena eggs under different conditions of water stress. Exp Parasitol. 2017;177:47-56.

97. Maya C, Ortiz M, Jiménez B. Viability of Ascaris and other helminth genera non larval eggs in different conditions of temperature, lime $(\mathrm{pH})$ and humidity. Water Sci Technol. 2010;62:2616-24.

98. Buttar BS, Nelson ML, Busboom JR, Hancock DD, Walsh DB, Jasmer DP. Effect of ensilation of patato on viability of Taenia hydatigena eggs. Exp Parasitol. 2013;133:483-6.

99. Negita T, Ito A. In vitro hatching of oncospheres of Taenia taeniaeformis using eggs isolated from fresh, frozen, formalin-fixed and ethanol-fixed segments. J Helminthol. 1994;68:271-2.

100. Konno K, Oku Y, Sakai H, Kamiya M. Effect of ultraviolet radiation on the infectivity of Taenia taeniaeformis eggs. Jpn J Vet Res. 1997;45:75-9.

101. Lagapa JTG, Konno K, Oku Y, Nonaka N, Kamiya M. Inhibitory effect of different UV lamps on the infectivity of taeniid eggs. Parasitol Res. 2001:87:593-7.

102. Maya C, Torner-Morales FJ, Lucario ES, Hernández E, Jiménez B. Viability of six species of larval and non-larval helminth eggs for different conditions of temperature, pH and dryness. Water Res. 2012;46:4770-82.

103. Adanir $R$, Tasci F. Prevalence of helminth eggs in raw vegetables consumed in Burdur. Turkey Food Control. 2013;31:482-4.

104. Nooraldeen K. Contamination of public squares and parks with parasites in Erbil city. Irak Ann Agri Environ Med. 2015:22:418-20.

105. Camacho SPD, Ruiz AC, Peraza VS, Ramos MLZ, Medina MF, Lozano $R$, et al. Epidemiologic study and control of Taenia solium infections with praziquantel in a rural village of Mexico. Am J Trop Med Hyg. 1991:46:522-31.

106. Maikai BV, Umoh JU, Ajanusi OJ, Ajogi I. Public health implications of soil contaminated with helminth eggs in the metropolis of Kadanu. Nigeria J Helminthol. 2008;82:113-8.

107. Özkayhan MA. Soil contamination with ascarid eggs in playground in Kirikkale. Turkey J Helminthol. 2006:80:15-8.

108. Pray IW, Gamboa R, Elizalde M, Gomez LA, Vilchez P, Muro C, et al. Detection of Taenia eggs in soil after mass anti-helminthic treatment: results from a community-wide soil sampling in Northern Peru. Am Soc Trop Med Hyg. 2018;486:153.

109. Aghaindum AG, Landry FKA. Dissemination of the resistant forms of intestinal worms in the marshy areas of the city of Yaounde
(Cameroon): importance of some abiotic factors of the medium. Appl Water Sci. 2019;9:19.

110. Chaoua S, Boussaa S, Khadra A, Boumezzough A. Efficiency of two sewage treatment systems (activated sludge and natural lagoons) for helminth egg removal in Morocco. J Infect Public Health. 2018;11:197-202.

111. Madera CA, Pena MR, Mara DD. Microbiological quality of waste stabilization pond effluent used for restricted irrigation in Valle Del Cauca. Colombia Water Sci Technol. 2002;45:139-43.

112. Mahvi AH, Kia EB. Helminth eggs in raw and treated wastewater in the Islamic Republic of Iran. East Mediter Health J. 2006;12:137-43.

113. Bouhoum K, Amahmid O, Asmama S. Occurrence and removal of protozoan cysts and helminth eggs in waste stabilization ponds in Marrakech. Water Sci Technol. 2000:42:159-64.

114. Canon-Franco WA, Henao-Agudelo RA, Perez-Bedoya JL. Recovery of gastrointestinal swine parasites in anaerobic biodigester systems. Rev Bras Parasitol Vet. 2012;21:249-53.

115. Verbyla ME, Oakley SM, Lizima LA, Zhang J, Iriarte M, Tejada-Martinez $A E$, et al. Taenia eggs in a stabilization pond system with poor hydraulics: concern for human cysticersosis? Water Sci Technol. 2013;68:2698-703.

116. Thomaz-Soccol V, Paulino RC, Castro EA, Andreoli CV. Helminth eggs viability in sewage and biosolids sludge in Curitiba, Parana. Braz Arquivos Biol Technol. 1997;40:829-36.

117. Dudlova A, Juris P, Jarcuska P, Cislakova L, Papajova I, Krcmery V. Epidemiological risks of endoparasitoses spread by municipal wastewater. Helmintologia. 2015;52:188-94.

118. Barbier D, Perrine D, Duhamel C, Doublet R, Georges P. Parasitic hazard with sewage sludge applied to land. Appl Environ Microbiol. 1990;56:1420-2.

119. Crewe W. The transmission of Taenia saginata in Britain. Ann Trop Med Parasitol. 1984:78:249-51.

120. El Fels L, El Hayany B, El Faiz A, Saadani M, Houari M, Hafidi M. Sludge nematodes, cestodes, activated sludge and infiltration-percolation wastewater treatment system under semi-arid climate. Env Sci Poll Res. 2019:26:570-6.

\section{Publisher's Note}

Springer Nature remains neutral with regard to jurisdictional claims in published maps and institutional affiliations.
Ready to submit your research? Choose BMC and benefit from:

- fast, convenient online submission

- thorough peer review by experienced researchers in your field

- rapid publication on acceptance

- support for research data, including large and complex data types

- gold Open Access which fosters wider collaboration and increased citations

- maximum visibility for your research: over $100 \mathrm{M}$ website views per year

At BMC, research is always in progress.

Learn more biomedcentral.com/submissions 